\title{
Qualitative Chemical Characterization of Some Milk Brands Popularly Consumed in North Central Nigeria
}

\author{
BEETSEH C. I. UDU S. S. KODOUN D. A. \\ Federal University of Agriculture Makurdi (FUAM) \\ Nasarawa State University Keffi (NSUK)
}

\begin{abstract}
This Work was carried out within the cities of Makurdi, Lafia and Keffi of North Central Nigeria on milk brands popularly consumed knowing the nourishing potentials of milk generally, it became expedient to assess its quality in the first instance in order to open up opportunities for further work. The milk brands were DANO , HOLLANDIA, PEAK ,COWBELL SOYMILK (made from soybeans) and FARM FRESH from cow milk. Parameters considered were appearance of milk - colour, organoleptic properties, acidity test , clot on boiling (C.O.B) test and grade of milk. Results showed that these brands had close characteristics despite the difference in their sources. $\mathrm{pH}$ was between 6.4 and 6.7, appearance of milk colour whitish and yellowish, organoleptic properties showed plain or pleasant tastes while acidity \% from 0.21 to 0.24 for all the brands. However some slight disparity at levels of handling occurred especially those exposed to heat in open marketing .These results showed how delicate it is to handle milk both for consumption as well as marketing its bye products and further research.
\end{abstract}

Keywords: Acidity, Hygienic, Yogurt ,Nutritional and Energy

DOI: $10.7176 /$ FSQM/86-07

Publication date: April $30^{\text {th }} 2019$

\section{Introduction}

Milk is a nutrient-rich, white - yellow liquid or solid food an emulsion of fat and protein in water, along with dissolved sugar (carbohydrate), minerals, and vitamins and is the primary source of nutrition for infant mammals. People enjoy drinking milk in its natural form and also use it to make a wide range of food products, including cream, butter, yogurt, cheese, and ice cream. Owen, E., et al. 2005

\subsection{Milk Production}

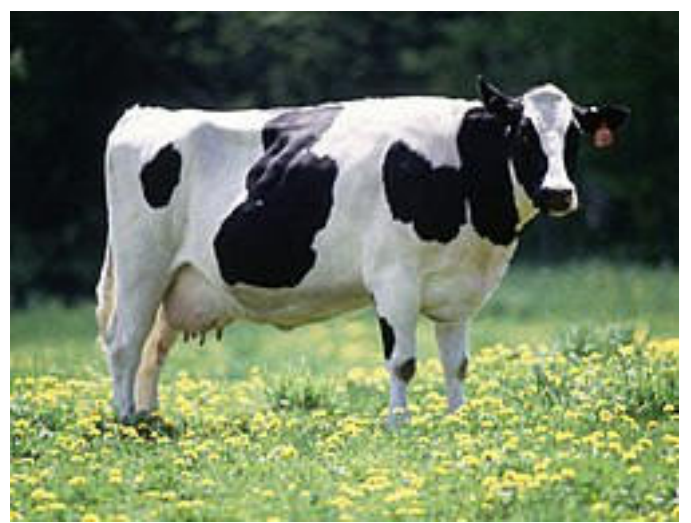

Figure 1: A Cow ready to be milked

The breast is a gland consisting primarily of connective and fatty tissues that support and protect the milk producing areas of the body. The milk is produced in small clusters of cells called areola which milk travels down to the nipples. Each nipple has 15 to 20 openings for milk to flow. Infant suckling or external pressure stimulates the nerve endings in the nipple and areola, which signal the pituitary gland in the brain to release two hormones, prolactin and oxytocin. Prolactin causes areola to take nutrients (proteins, sugars) from the blood supply and turn them into breast milk. Oxytocin causes the cells around the areola to contract and eject milk down the ducts. This passing of the milk down the ducts is called the "let-down" (milk ejection) IDF Doc. No.9002

Approximately 150 million households around the globe are engaged in milk production. In most developing countries, milk is produced by smallholders, and it contributes to household livelihoods, food security and nutrition. Milk provides relatively quick returns for small-scale producers and is an important source of cash income. In recent decades, developing countries have increased their share in global dairy production, this is mostly the result of an increase in numbers of producing animals rather than a rise in productivity per head. In many developing countries, dairy productivity is constrained by poor-quality feed resources, diseases, limited 
access to markets and services and dairy animals' low genetic potential for milk production. Bouguedour, R. and S. Ichou, (2010)

\subsection{Milk Composition}

The milk of animals that grow rapidly, such as cows, which double their birth weight in 50 days, is rich in protein and minerals; composed of 80 percent water, 5 percent fat, characteristic taste and texture, vitamins $\mathrm{A}, \mathrm{D}, \mathrm{E}$, and $\mathrm{K}$, as well as certain fatty acids. It contains many minerals, the most abundant of which are calcium and phosphorus and an excellent source of vitamins $A$ and $B_{2}$. Vitamin $A$, is found in the globules of fat and is removed when fat is skimmed away to make low-fat or skim milk.

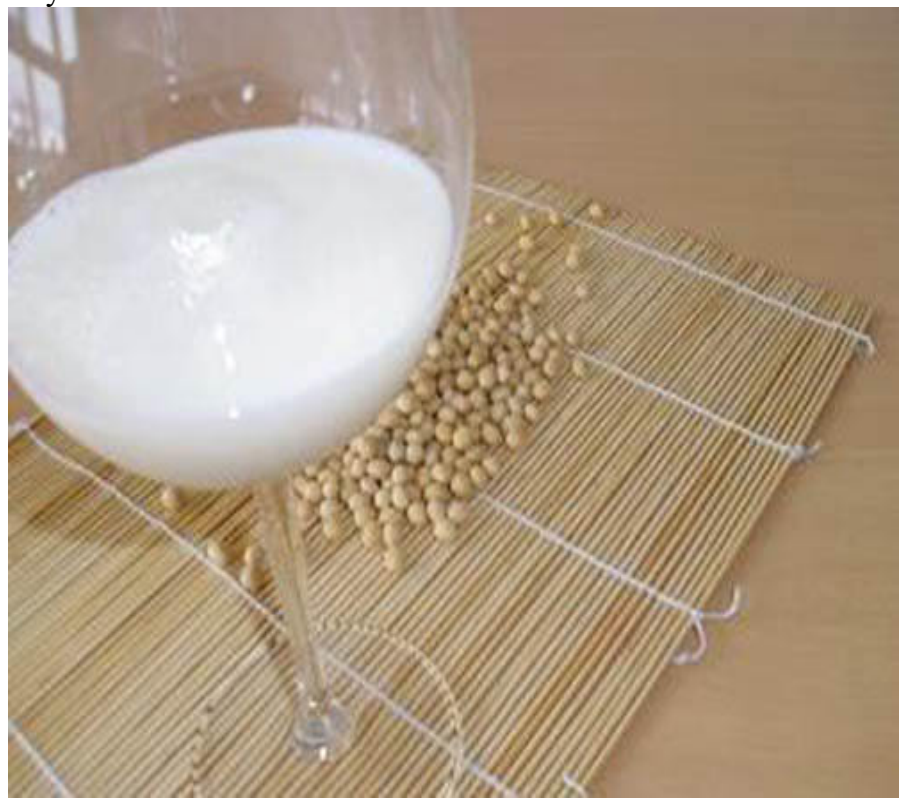

Figure 2: Soybean seeds and milk

Soymilk is made from soybeans that have been soaked in water, ground, and strained. Fortified soy milk (which has added calcium and vitamin D) can be used instead of animal milk as a drink on cereals and in other recipes. Soy milk comes plain and in different flavors such as chocolate and vanilla. According to AdjlaneKaouche, S.et al (2014) human milk provides distinct advantages over vegetable or cow milk for human infants. Not only is breast milk's nutritional composition uniquely designed for the needs of human babies, but it also contains antibodies from the mother's immune system that help the infant fight off infections and diseases. During the first few days after giving birth, a mother releases colostrum, a yellowish liquid that contains less fat and lactose and more protein and antibodies than regular breast milk. After about three or four days, colostrum is replaced by a bluish-white milk that is higher in fats and carbohydrates, reflecting the energy needs of a growing baby, contains calcium which builds healthy bones and teeth; maintains bone mass, contains Protein, Potassium , Vitamin D , B12 and Phosphorus which serves as a source of energy; builds and repairs muscle tissue , helps maintain a healthy blood pressure, strengthens bones, generates energy, maintains healthy red blood cells and nerve tissue. Milk is also a rich source of chorine; an important nutrient found to support sleep, muscle movement, learning and memory, helps to maintain the structure of cellular membranes, aids in the transmission of nerve impulses, assists in the absorption of fat and can lessen chronic inflammation

\subsection{Milk Products}

Milk is expressed in various forms for its consumption- raw milk which is milk that has not been pasteurized to kill harmful bacteria can come from any animal and carries dangerous germs whole milk has its fat content lowered to 3 percent,. Skim Milk or nonfat milk, is the liquid that remains after removing all the cream; it contains about half a percent milk fat. For most toddlers, cow's milk is generally a better choice because it is more nutrient dense and naturally contains more vitamins, protein and minerals than soy milk. So, the choice of milk for children is dependent on the nutritional needs and restrictions, as well as the taste preferences of the child.. Cream contains 18 percent milk fat, Butter a dairy product with high butterfat content which is solid when chilled and at room temperature in some regions, and liquid when warmed. It is made by churning fresh or fermented cream or milk to separate the butterfat from the buttermilk. It is generally used as a spread on plain or toasted bread products and a condiment on cooked vegetables, as well as in cooking, such as baking, sauce making, and pan frying. Butter consists of butterfat, milk proteins and water, and often added salt. iii cultured buttermilk and sour cream, like 
yogurt, are produced by the breakdown of lactose by bacteria .iv Ice Cream is a frozen dairy food made from cream or butterfat, milk, sugar, and flavourings the most popular being vanilla, chocolate, strawberry and sometimes contain eggs .v Yogurt semifluid fermented milk food having a smooth texture and mildly sour flavour because of its lactic acid content is made from the milk of cows, sheep, goats, or water buffalo usually made from milk that has been fortified by the addition of nonfat powdered milk to improve its texture and taste. The fortified milk is pasteurized at a very high temperature and homogenized. A culture containing the bacteria Streptococcus thermophilus and Lactobacillus bulgaricus, and sometimes Lactobacillus acidophilus, is then added. In Cheese making bacteria are introduced into milk that consume lactose and produce lactic acid. Cheeses are allowed to ferment longer than yogurt, buttermilk, and sour cream, which gives the bacteria time to also digest some of the fat and protein present. The waste products produced by bacteria from digesting fats and proteins provide cheeses with their distinctive and stronger flavors. also contains calcium which builds healthy bones and teeth; maintains bone mass, it ontains Protein, Potassium, Vitamin D, B12 Phosphorus which serves as a source of energy; builds/repairs muscle tissue, Helps maintain a healthy blood pressure, strengthen bones, generate energy ,Maintains healthy red blood cells and nerve tissue. Milk is also a rich source of chorine; an important nutrient found to support sleep, muscle movement, learning and memory. it helps to maintain the structure of cellular membranes, aids in the transmission of nerve impulses, assists in the absorption of fat and can lessen chronic inflammation.

\subsection{Dry Milk Products}

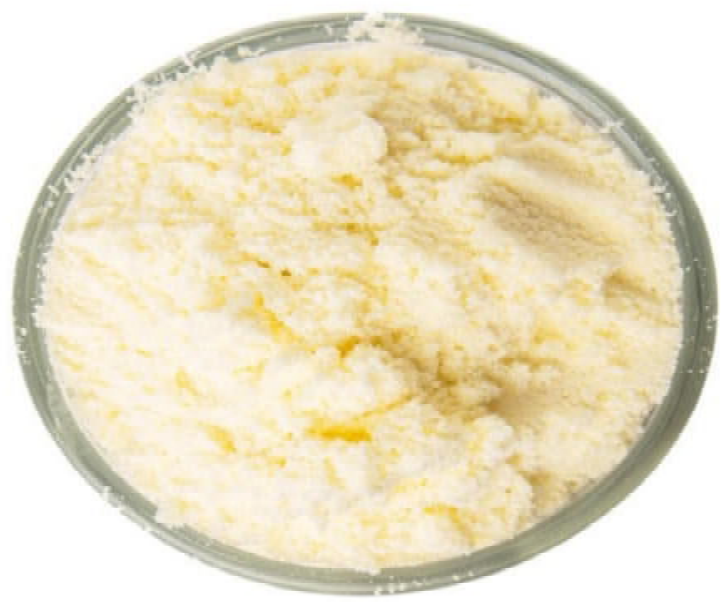

Fig 3 Dried milk in a bowl

According to K.N. Pearce and F, Glenn. (2018.) milk and milk products are often dried to less than 4 percent moisture to prevent bacterial growth and spoilage, to reduce weight and to extend shelf life .Two types of dryers are used in the production of dried milk products - drum dryers and spray dryers. The simplest and least expensive is the drum, or roller, dryer. It consists of two large steel cylinders that turn toward each other and are heated from the inside by steam. The concentrated product is applied to the hot drum in a thin sheet that dries during less than one revolution and is scraped from the drum by a steel blade. The flake like powder dissolves poorly in water but is often preferred in certain bakery products. Drum dryers are also used to manufacture animal feed where texture, flavour, and solubility are not a major consideration.

\subsubsection{Spray dryers}

Spray dryers are more commonly used since they do less heat damage and produce more soluble products. Concentrated liquid dairy product is sprayed in a finely atomized form into a stream of hot air. The air may be heated by steam-heated "radiators" or directly by sulfur-free natural gas. The drying chamber may be rectangular (the size of a living room), conical, or silo-shaped (up to five stories high). The powder passes from the drying chamber through a series of cyclone collectors and is usually placed in plastic-lined, heavy-duty paper bags.

Spray-dried milk is also difficult to reconstitute or mix with water. Therefore, a process called agglomeration was developed to "instantize" the powder, or make it more soluble. This process involves rewetting the fine, spraydried powder with water to approximately 8 to 15 percent moisture and following up with a second drying cycle. The powder is now granular and dissolves very well in water. Virtually all retail packages of nonfat dry milk powder are instantized in this manner. 


\subsection{Lactic Acid}

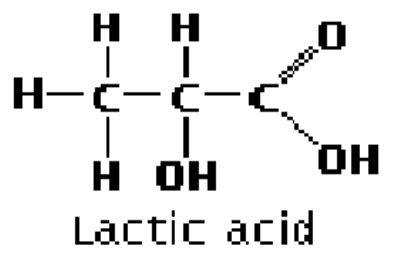

Lactic acid (formula $\mathrm{C}_{3} \mathrm{H}_{6} \mathrm{O}_{3}$ ). discovered in sour milk in the late 1700's. is an alpha-hydroxy acid (AHA) because of the hydroxyl group adjacent to the carboxyl group, The presence of lactic acid or lactate in milk is due to the fermentation of lactose caused mainly by lactic bacteria. Generally speaking, just-milked milk does not contain lactic acid, but this increases after a while and its concentration is closely correlated to the total bacterial charge .In its solid state, it is white and water-soluble. In its liquid state, it is colorless. It is produced both naturally and synthetically, in the body it breaks down almost immediately into lactate and hydrogen ions, what persists in the body is lactate and is an organic ion with a negative charge, with chemical formula $\mathrm{C}_{3} \mathrm{H}_{5} \mathrm{O}_{3}$ and found in every cell in the body. The technical difference between lactate and lactic acid is chemical. Lactate is lactic acid, missing one proton. To be an acid, a substance must be able to donate a hydrogen ion; when lactic acid donates its proton, it becomes its conjugate base, or lactate. ... But, the body produces and uses lactate -- not lactic acid When the oxygen level is low, carbohydrate breaks down for energy and Lactate is one of the substances produced by cells as the body turns food into energy (cell metabolism), with the highest level of production occurring in the muscles. Depending on $\mathrm{pH}$, it is sometimes present in the form of lactic acid. However, with the neutral $\mathrm{pH}$ maintained by the body, most of it will be present in the blood in the form of lactate. Lactic acid levels get higher when strenuous exercise or other conditions - such as heart failure, a severe infection (sepsis), or shock - lower the flow of blood and oxygen occurs . A high lactate level in the blood means that the disease or condition a person has is causing lactate to accumulate. In general, a greater increase in lactate means a greater severity of the condition. When associated with lack of oxygen, an increase in lactate can indicate that organs are not functioning properly. Increased lactate levels may be seen with thiamine (vitamin B1) deficiency certain medications, including metformin and HIV drugs, can cause high lactate levels if elevated lactate level is due to an underlying condition that can be addressed, such as uncontrolled diabetes or a substance that can be avoided, such as ethanol, then one may be able to lower it. If one has been diagnosed with a condition, such as a metabolic disorder, following ones prescribed treatment regimen should control lactate levels. If the increase is due to a temporary condition, such as shock or infection, then it will usually return to normal after the condition has been resolved. Ivanov A, Mukhtarov M, Bregestovski P, Zilberter Y (2011).

\section{Bacteria in milk}

Milk is an excellent growth medium for numerous bacteria, and the bacteria can increase rapidly in numbers unless the milk is properly processed. Bacterial growth can spoil the milk or even pose a serious health hazard if pathogenic bacteria are present. Certain bacteria convert milk into useful dairy products, such as buttermilk, yogurt, and cheese. Commercially cultured buttermilk is prepared from skim milk inoculated with a starter culture of Streptococcus lactis or S. cremoris, together with Leuconostoc citrovorum or L. dextranicum. The combined action of Streptococcus and Leuconostoc consumes the milk sugar, produces lactic acid, and precipitates milk protein (casein). Yogurt and other fermented milk products are produced in a similar manner using different cultures of bacteria. When Lactococcus lactis is added to milk, the bacterium uses enzymes to produce energy (ATP) from lactose. The byproduct of ATP production is lactic acid. The lactic acid curdles the milk that then separates to form curds, which are used to produce cheese. (Swai, E.S. and L. Schoonman, 2011).

\subsection{Pasteurization}

Pasteurization is a partial sterilization accomplished by raising the milk to a temperature high enough to destroy pathogenic bacteria and a large proportion of those causing spoilage. It is named after the French scientist Louis Pasteur, who in the 1860 s demonstrated that abnormal fermentation of wine and beer could be prevented by heating the beverages to about $57^{\circ} \mathrm{C}$ for a few minutes. The times and temperatures are those determined to be necessary to destroy the Mycobacterium tuberculosis and other more heat-resistant of the non-spore-forming, diseasecausing microorganisms found in milk. The treatment also destroys most of the microorganisms that cause spoilage and so prolongs the storage time of food. Pasteurized milk that is kept refrigerated in closed containers will remain consumable for approximately 14 days.

\subsection{Packaging}

Aseptic packaging is used for packaging milk and it involves heat sterilization of milk and the package sterilized 
separately allowing the milk to retain more nutrients and better flavor. Containers are sterilized with hydrogen peroxide rather than with heat, permitting the use of plastic bags and foil-lined cartons, which would be destroyed by heat sterilization. Aseptically packaged milk will keep without refrigeration for long periods of time and still maintain good taste, nutrition and convenience.

\subsection{Fermentation}

Fermentation is a chemical reaction carried out by many types of microorganisms to obtain energy, they break down complex organic compounds into simpler substances and is desirable and microorganisms are actually added to foods. For example, in the production of beer, wine, and other alcoholic beverages, yeasts convert sugar into ethyl alcohol and carbon dioxide. In the making of yogurt and cheese, bacteria convert lactose a sugar found in milk, to lactic acid. Alcohol, acids, and other compounds produced in fermentation act as preservatives, inhibiting further microbial growth. In addition to its use with alcoholic beverages, cheese, and yogurt, fermentation is used to produce yeast bread and soy sauce.

\subsection{Testing milk}

Milk being made up of $87 \%$ water is prone to adulteration; its high nutritive value makes it an ideal medium for the rapid multiplication of bacteria, particularly under unhygienic production and storage at ambient temperatures. Faye, B. \& Konuspayeva, G. (2012) A milk processor or handler will only be assured of the quality of raw milk if certain basic quality tests are carried out at various stages of transportation of milk from the producer to the processor and finally to the consumer, it is marketed in liquid state pasteurized and sealed in packs and tins in a refrigerated environment or dry heat sealed sachets packed in bags in open stores and markets. The tests were carried out by buying random samples as presented in air-conditioned stores at room temperatures of $20-28{ }^{\mathrm{OC}}-$ class $\mathrm{A}$ on the one hand and open retail markets which assumes ambient temperatures of $30-40^{\mathrm{OC}}-$ class $\mathrm{B}$ on the other. The scope of this work for now seeks to characterize the milk encountered and used daily in order to obtain basic information for further use. Maxprosol (2017)Most of the work was done in the laboratory of Makurdi water works .

\subsection{Milk Handling}

The milk already packaged for distribution is sent to the consumer either to stores refrigerated or open markets at ambient temperatures.

\subsection{Apparatus for testing.}

Water bath, refrigerator, test tubes, flasks, thermometer ,pH meter, Phenolphthalein indicator, 0.1 M Sodium hydroxide .

\subsection{Milk Sampling}

To ensure accurate sampling as the first pre-requisite for fair and just quality milk sampling liquid milk of the different varieties were thoroughly mixed to disperse the milk fat before a sample was taken . Representative samples of dry packed products were also taken and dissolved in water for testing. Milk samples were kept cool in a refrigerator after warming in water bath at $40^{\circ} \mathrm{C}$ and cooled to $20^{\circ} \mathrm{C}$.

\subsection{Organoleptic Tests}

According to The Gale (2010 ) Organoleptic testing is the analysis of the properties of products and materialsmainly foodstuffs - by means of the sense organs usually to evaluate their quality .Perceptions among different persons as well as in a single person may vary depending on the state of the body. It is used where other scientific methods of testing are not available.

As a can or a sachet of milk was opened the milk tester with a good sense of sight, smell and taste tested the milk and obtained the results that very moment .

\subsection{Clot on Boiling (C.O.B) Test}

If milk is kept at room temperature, there will be increase in acidity which is described as developed acidity. If acidity is increased to more than 0.2 percent, there is coagulation due to heat treatment, which is the result of dissociation of calcium caseinate salt. Hence it is essential to know the heat stability of incoming raw milk for further processing. The appearance of Clots in the milk sample at boiling is a qualitative method of its acidity determination. Marshall, R.T. 1992. A small amount of milk was boiled in a test tube to see if there was clotting, coagulation or precipitation in any of the samples.

\subsection{Acidity}

It is important to know the acidity of dairy products, due to some constituents which make up this acidity in milk 
such as Casein ., Phosphates, Citrates, Nitrogen, Potassium, Zinc, Boron and $\mathrm{CO}_{2}$ There are qualitative and quantitative methods of acidity determination for milk we measure the acidity by measuring lactic acid percentage

$9 \mathrm{ml}$ of liquid as well as the dissolved dry milk was measured into a conical flask, $1 \mathrm{ml}$ Phenolphthalein indicator was added and then slowly from the burette, $0.1 \mathrm{M}$ Sodium hydroxide under continuous mixing, until a faint pink colour appeared. The number of milliliters of Sodium hydroxide solution divided by 10 expresses the percentage of lactic acid.

\section{0 Discussion}

There was no contamination, clotting, coagulation nor precipitation in the milk samples in class A group and their acidity below $0.20-0.26 \%$ Lactic acid .In class B there is observation of increase in the percentage of lactic acid in all the samples. The organoleptic qualities did not change but the grade was a little bit altered downward from very good to good. Leaving milk under normal temperature such as room temperature allows for the growth of bacteria already present in the milk especially the Lactic acid bacterial strains which convert the Lactose (milk sugar) to Lactic acid by fermentation decreasing the $\mathrm{pH}$ and increasing the milk acidity, this acidity is called developed acidity since it was developed from an organism which is the Lactic acid bacteria.

\section{0 Conclusion}

Manufacturing of milk, some dairy products and the milk stability makes it necessary for certain tests to be carried out like the tests of clot on boiling test $(\mathrm{COB})$, qualitative method of acidity determination and $\mathrm{pH}$. Milk has its uses worldwide that has been well documented and its abundance is also not in doubt so is its research. This work has brought out the goodness of product quality despite obvious difference in handling atmosphere as well as efficacy of production especially packaging which is very safe and intact .Further work is open and attainable.

Milk Quality Analysis

By Maxprosol (2017) Milk Testing Services

\begin{tabular}{ccc} 
Parameters & Measure Range & Accuracy \\
FAT & from $0.01 \%$ to $45 \%$ & $\pm 0.01 \%$ \\
\hline Solids-non-fat (SNF) & from $3 \%$ to $40 \%$ & $\pm 0.15 \%$ \\
\hline Density & from $1015 \mathrm{~kg} / \mathrm{m}^{3}$ to $1160 \mathrm{~kg} / \mathrm{m}^{3}$ & $\pm 0.3 \mathrm{~kg} / \mathrm{m}^{3}$ \\
\hline Protein & from $2 \%$ to $7 \%$ & $\pm 0.15 \%$ \\
\hline Lactose & from $0.01 \%$ to $6 \%$ & $\pm 0.2 \%$ \\
\hline Added water & from $0 \%$ to $70 \%$ & $\pm 1 \%$ \\
\hline Milk sample temperature & from $1{ }^{\circ} \mathrm{C}$ to $40{ }^{\circ} \mathrm{C}$ & $\pm 0.001 \%$ \\
\hline Freezing point & from $-0.4{ }^{\circ} \mathrm{C}$ to $-0.7{ }^{\circ} \mathrm{C}$ & $\pm 0.05 \%$
\end{tabular}


Results of the Tests carried out on milk in stores at room temperatures of $20-28^{\circ \mathrm{CC}}$ class A

\begin{tabular}{|c|c|c|c|c|c|c|c|}
\hline Parameter & $\begin{array}{l}\text { Milk } \\
\text { type }\end{array}$ & $\begin{array}{l}\text { FARM } \\
\text { FRESH } \\
\text { (liquid) }\end{array}$ & $\begin{array}{l}\text { COWBELL } \\
\text { (solid) }\end{array}$ & $\begin{array}{l}\text { DANO } \\
\text { (solid) }\end{array}$ & $\begin{array}{l}\text { HOLLAN } \\
\text { DIA } \\
\text { (liquid) }\end{array}$ & $\begin{array}{l}\text { PEAK } \\
\text { (liquid) }\end{array}$ & $\begin{array}{l}\text { Soymilk } \\
\text { (liquid) }\end{array}$ \\
\hline $\mathrm{PH}$ & & 6.4 & 6.5 & 6.7 & 6.7 & 6.7 & 6.6 \\
\hline $\begin{array}{l}\text { Appearance } \\
\text { of milk } \\
\text { Colour }\end{array}$ & & whitish & Yellowish & whitish & whitish & Yellowish & Yellowish \\
\hline $\begin{array}{ll}\text { Clot } & \text { on } \\
\text { Boiling } & \\
\text { (C.O.B) } & \\
\end{array}$ & & $\begin{array}{l}\text { No } \\
\text { coagulation } \\
\text { no lumps } \\
\end{array}$ & $\begin{array}{l}\text { No } \\
\text { Coagulation } \\
\text { no lumps }\end{array}$ & $\begin{array}{l}\text { No } \\
\text { coagulation } \\
\text { no lumps } \\
\end{array}$ & $\begin{array}{l}\text { No } \\
\text { coagulatio } \\
\text { n no lumps } \\
\end{array}$ & $\begin{array}{l}\text { No } \\
\text { coagulation } \\
\text { no lumps } \\
\end{array}$ & $\begin{array}{l}\text { No } \\
\text { coagulation } \\
\text { no lumps } \\
\end{array}$ \\
\hline $\begin{array}{l}\text { Organoleptic } \\
\text { properties }\end{array}$ & & $\begin{array}{l}\text { Pleasant } \\
\text { taste }\end{array}$ & Plain taste & Plain taste & $\begin{array}{l}\text { Pleasant } \\
\text { taste }\end{array}$ & $\begin{array}{l}\text { Pleasant } \\
\text { taste }\end{array}$ & Plain taste \\
\hline Grade of milk & & $\mathrm{V}$ good & good & good & $\mathrm{V}$ good & $\mathrm{V}$ good & good \\
\hline Acidity \% & & 0.24 & 0.21 & 0.23 & 0.22 & 0.24 & 0.24 \\
\hline
\end{tabular}

Results of the Tests carried out on milk in open retail markets with ambient temperatures of $30-40^{\circ C}$ class B

\begin{tabular}{|l|l|l|l|l|l|l|l|}
\hline Parameter & $\begin{array}{l}\text { Milk } \\
\text { type }\end{array}$ & $\begin{array}{l}\text { FARM } \\
\text { FRESH } \\
\text { (liquid) }\end{array}$ & $\begin{array}{l}\text { COWBELL } \\
\text { (solid) }\end{array}$ & $\begin{array}{l}\text { DANO } \\
\text { (solid) }\end{array}$ & $\begin{array}{l}\text { HOLLANDIA } \\
\text { (liquid) }\end{array}$ & $\begin{array}{l}\text { PEAK } \\
\text { (liquid) }\end{array}$ & $\begin{array}{l}\text { Soymilk } \\
\text { (liquid) }\end{array}$ \\
\hline PH & & 6.2 & 6.0 & 6.2 & 6.1 & 6.4 & 5.8 \\
\hline $\begin{array}{l}\text { Appearance } \\
\text { of milk } \\
\text { Colour }\end{array}$ & whitish & Yellowish & whitish & whitish & Yellowish & Yellowish \\
\hline $\begin{array}{l}\text { Clot on } \\
\text { Boiling } \\
\text { (C.O.B) }\end{array}$ & & $\begin{array}{l}\text { No } \\
\text { coagulation } \\
\text { no lumps }\end{array}$ & $\begin{array}{l}\text { No } \\
\text { Coagulation } \\
\text { no lumps }\end{array}$ & $\begin{array}{l}\text { No } \\
\text { coagulation } \\
\text { no lumps }\end{array}$ & $\begin{array}{l}\text { No coagulation } \\
\text { no lumps }\end{array}$ & $\begin{array}{l}\text { No } \\
\text { coagulation } \\
\text { no lumps }\end{array}$ & $\begin{array}{l}\text { No } \\
\text { coagulation } \\
\text { no lumps }\end{array}$ \\
\hline $\begin{array}{l}\text { Organoleptic } \\
\text { properties }\end{array}$ & & Plain taste & Plain taste & Plain taste & Plain taste & Plain taste & Plain taste \\
\hline $\begin{array}{l}\text { Grade of } \\
\text { milk }\end{array}$ & good & good & good & good & good & good \\
\hline Acidity \% & & 0.21 & 0.24 & 0.22 & 0.23 & 0.24 & 0.22 \\
\hline
\end{tabular}

\section{References}

^ Ivanov A, Mukhtarov M, Bregestovski P, Zilberter Y (2011). "Lactate Effectively Covers Energy Demands during Neuronal Network Activity in Neonatal Hippocampal Slices". Frontiers in Neuroenergetics. 3: 2. doi:10.3389/fnene.2011.00002. PMC 3092068. PMID 21602909. $\square \quad$ Buffers \& Saturating agents http://www.interchim.fr/ft/B/BA352a. https://archive.org/details/foodstheircompos00blyt

${ }^{\wedge}$ K.N. Pearce, F Glenn. (2018.) Milk Powder "Density". The Physics Hypertextbook.

$\wedge$ The Gale (2010) The Great Soviet Encyclopedia, 3rd Edition (1970-1979).

^ Zena D. Hosking H. Barkworth ( 2009) https://doi.org/10.1017/S0022029900008876

^ Maxprosol (2017) Milk Testing Services Email:info@milktestingservices.com Community Engagement Program.

Robert Kad ner (2014) Bacteria.. Encyclopædia Britannica. Encyclopædia Britannica Ultimate Reference Suite. Chicago:

$\wedge \quad$ ISI Thomson -(2016 )Assessment of Microbiological Quality of Raw Milk Produced at Tizi ...https://scialert.net/fulltext/?doi=ajava.2016.854.860

$\wedge$ Mestdagh $\mathrm{F}^{1}$, ET AL (2005) Influence of several packaging materials on light oxidation of milk.

$\wedge$ Ana Carolina Chang ( 2017) Effects of LED and Fluorescent Light on the Flavor of Milk and Strategies to Mitigate Milk Oxidation.

${ }^{\wedge}$ Marshall, R.T. (1992) Standard Methods for the determination of Dairy Products. $16^{\text {th }}$ ed. Publ. American Public Health Association.

$\wedge$ IDF Doc. No.9002, Handbook on Milk collection in Warm Developing Countries. International Dairy Federation, Brussels, Belgium

$\wedge$ Adesiyun, A.A., S. Stoute and B. David, 2007. Pre-processed bovine milk quality in Trinidad: Prevalence and characteristics of bacterial pathogens and occurrence of antimicrobial residues in milk from collection centres. Food Control, 18: 312-320. 
$\wedge$ Adjlane-Kaouche, S.et al ( 2014) Nutritional and hygienic quality of raw milk in the mid-northern region of Algeria: Correlations and risk factors. Scient. World J. 10.1155/2014/131

$\wedge$ Aggad, H. et al( 2009) [Assessment of milk hygienic quality in Western Algeria]. Revue Medecine Veterinaire, 12: $590-595$.

$\wedge$ Bonfoh, B., Simbe et al (2006) Effect of washing and disinfecting containers on the microbiological quality of fresh milk sold in Bamako (Mali). Food Control, 17: 153-161.

$\wedge$ Bouguedour, R. and S. Ichou, (2010) The dairy industry in the renewal of the agricultural economy. Communication at the 8th Day of Veterinary Science, Algiers, April 18-19, 2010.

$\wedge$ Djermoun, A. and F. Chehat,( 2012). [The development of the dairy industry in Algeria: Self-sufficiency to dependence]. Livest. Res. Rural Dev., Vol. 24, No. 1.

${ }^{\wedge}$ El Marnissi, B., R et al(2013). [Microbiological and physicochemical characterization of raw milk and some Moroccan traditional dairy derivatives (Lben and Jben)]. Les Technologies Laboratoire, 8: 100-111,

$\wedge$ Faye, B. and G. Loiseau (2002). Sources of Contamination in Dairy Supply Chains and Approaches to Quality Control. In: Food Safety Management in Developing Countries: Proceedings of the International Workshop, CIRAD-FAO, 11-13 December 2000, Montpellier (France), Ellen, H., B. Ezzedine, F. Pierre and P. Maya (Eds.). CIRAD/FAO., Montpellier, France, ISBN-13: 9782876144217.

${ }^{\wedge}$ Ghazi, K. and A. Niar,(2011). [Hygienic quality of cow milk, in various bovine breeds of Tiaret area (Algeria)]. Tropicultura, 29: 193-196, (In French).

$\wedge$ Ghazi, K., B. Guessas, A. Niar and K.I. Louacini, (2010) Hygienic quality of cow milk, in various bovine breeds of Tiaret area (Algeria). Asian J. Anim. Vet. Adv., 5: 592-596.

${ }^{\wedge}$ Hacini, N. ( 2007) Dairy industry and food risks. Mag. Vet. Rev., 58: 22-29.

$\wedge$ Hakem, A., B. et al.( 2012) Evaluation of microbial quality of raw milk into two dairies Mitidja's farms (Algeria). Bull. USAMV Vet. Med., 69: 272-281.

^ Kamal, R.M., et al,( 2013) MRSA detection in raw milk, some dairy products and hands of dairy workers in Egypt, a mini-survey. Food Control, 33: 49-53.

$\wedge$ Kivaria, F.M.et al ( 2006) Evaluation of the hygienic quality and associated public health hazards of raw milk marketed by smallholder dairy producers in the Dar es Salaam region, Tanzania. Trop. Anim. Health Prod., 38: 185-194.

^ Kouame-Sina, S.M., A. Bassa, A. Dadie, K. Makita, D. Grace, M. Dje and B. Bonfoh, 2010. [Microbial risk analysis of local raw milk in Abidjan (Cote d'Ivoire)]. Revue Africaine Sante Productions Animales, 8: 3542

$\wedge$ Mhone, T.A., G. Matope and P.T. Saidi, 2011. Aerobic bacterial, coliform, Escherichia coli and Staphylococcus aureus counts of raw and processed milk from selected smallholder dairy farms of Zimbabwe. Int. J. Food Microbiol., 151: 223-228.

${ }^{\wedge}$ Millogo, V., K.S. Sjaunja, G.A. Ouedraogo and S. Agenas, 2010. Raw milk hygiene at farms, processing units and local markets in Burkina Faso. Food Control, 21: 1070-1074.

$\wedge$ Srairi, M.T., H. Alaoui, A. Hamama and B. Faye, 2004. [Physical and chemical quality and antibiotics contamination of bulk milk in intensive dairy cattle farms in Morocco]. Rencontres Recherches Ruminants, 11: $115-115$.

$\wedge$ Swai, E.S. and L. Schoonman, 2011. Microbial quality and associated health risks of raw milk marketed in the Tanga region of Tanzania. Asian Pac. J. Trop. Biomed., 1: 217-2

^ Faye, B. \& Konuspayeva, G. (2012) The sustainability challenge to the dairy sector- The growing importance of non-cattle milk production worldwide. International Dairy Journal, 24 (2): 50-56.

^ Owen, E., Kitalyi, A., Jayasuriya, N., \& Smith, T. 2005. Livestock and wealth creation: improving the husbandry of animals kept by resource-poor people in developing countries. Nottingham, Nottingham University Press.

^ Park, Y.W. \& Haenlein, G.F.W., eds. 2006. Handbook of milk of non-bovine mammals. Iowa, USA, Blackwell Publishing.

^ World Bank. 2011. Module 4- Smallholder dairy production. Agriculture Investment Sourcebook, April 2013 (available at: http://go.worldbank.org/LE880YAAH0 